\title{
THE MEANS EMPLOYED BY BUTTERFLIES OF THE GENUS BASILARCHIA FOR THE PERPETUATION OF THE SPECIES.
}

\section{BY SAMUEL HUBBARD SCUDDER, CAMBRIDGE, MASS.}

The power of reproduction conceded, the universal instinct for self-preservation is the fundamental and controlling principle by which the perpetuation of any kind of animal is successfully reached. The uncontrollable maternal instinct of self-sacrifice existing in some animals alone overmasters it, and this exists only in the higher animals, which, compared with the great mass, are but few in number; and is then in most cases called into play only when the creature's life-work is nearly finished. No such instinct occurs among butterflies, nor is in any way likely to be found, so that "self-preservation" and "perpetuation of the species" are here, at least through all but the closing days of life, practically equivalent terms. The "struggle for existence" in the species and in the individual are largely convertible terms.

This struggle is the perpetual inheriance of the individual. The individual inherits alike its structure and its habits of life, which latter are very largely, perhaps almost absolutely, dependent on its structure; its tastes and its propensities, its fears and its devices to circumvent its enemies; all its instincts, which are to a great extent, possibly wholly, the entailment of ancestral habits; its very attitudes, whether at rest or in motion. Its advantages and its disadvantages are thus alike its legacy; so too the peculiar means it employs to disembarrass itself of these disadvantages. This is especially and more immediately true of the insect in its earlier stages, where freedom to change the immediate surroundings is exceedingly limited or altogether impossible, except so far as there is foresight, or an instinct marvellously akin to foresight on the part of the creature in an antecedent stage.

It is of more than usual interest to study the means of self-preservation in the genus Basilarchia, since there is hardly another genus of butterflies where throughout its entire life the insect is apparently so exposed to its enemies. They are all, of their kind, conspicuous objects even to our dull eyes, and more than that they are, with the exception of the chrysalis, always found in unusually conspicuous situations. How then do they manage to escape their keen sighted foes, the birds, or their wakeful, indefatigable, persistent enemies among the insect tribes,ichneumons, ants, wasps, flies, mites, and spiders?

Take first the egg-stage. Every one who has attempted to rear butterflies knows what immense destruction falls to the lot of any species at this stage in its life. Ants and spiders look on them as delicacies made for their delectation, and there is a whole group of tiny 
hymenoptera, almost too small to breathe, one would think, mere specks, which live solely upon insects' eggs, piercing them with their egg-darts, their progeny living imprisoned and feeding on the contents until they have run the cycle of their changes. Some attack whole batches of eggs, laying one egg in each, so that one parasite may destroy the entire brood of one butterfly; others lay their all in one or two eggs, and it is to this class that those belong which sting the eggs of Basilarchia. How does Basilarchia escape this danger? In the first place, the mother rarely lays more than one egg in one spot or even on one bush, though as many as a dozen or two may occasionally be found, where the butterfly's numbers are great and they are growing as it were imprudent. Then it must be remembered first that - to judge from the latest researchesthese parasitic flies must be guided less by vision than by touch; and second, that most insect eggs are laid on the broader parts of the leaf on which the young will feed; it is here that the parasite will range in quest of prey; but the eggs of Basilarchia are rarely found except at the extreme tips of leaves, and in addition the leaves of the food-plants concerned are all acuminate, some to an excessive extent, as in some of the poplars and birches. When the parasite has, however, found an egg, it may well be inquired whether she would not be deceived by it. It differs from the eggs of all our other butterfties, in that it is besprinkled with little flexible filaments for all the world like the hairs of some leaves. Or if the clothing of the eggs did not deceive, she might even then find it difficult of attack, for minute as these parasites are, less than half a millimetre long, their bodies would extend across at least three of the polygonal cells which regularly stud the surface of the egg, and which send forth these little filaments at every angle, so that poor bewildered madame must struggle through a weary chapparal before she can attain the barren grounds at the summit and find a spot to readily insert her sting. Yet that she succeeds is only too evident to the collector; the larger part of the eggs obtained in the open field which have fallen into my hands have been parasitized.

This is its but too partial defence against its special enemies. But how about those wandering buccancers, the ants, mites, and spiclers? These labor under the same visual defects as the direct parasites, or sometimes greater ones, and the position of the egg, remote from their usual hunting ground, must serve as no inconsiderable protection; how great, there are hardly means of measurement. Their greatest protection from these savages, which cannot fly but must wander ceaselessly about on foot in search of prey with satanic energy, is undoubtedly in the fewness of their number on one plant. The spider that finds two eggs of a Basilarchia in one day must be an excellent hunter.

Escaped at last from these dangers, 
which only lasted at the most ten days the caterpillar crawls forth from its prison and begins its active life. It is a scrawny juiceless looking thing, all covered with warts, and less than any other newly born caterpillar, would seem a tempting morsel even to an ichneumon or a spider. Yet both make havoc with it at this time. To a wandering ichneumon contact with an empty eggshell would probably mean, as a result of its inherited wisdom, that some nice young caterpillar was about, and the neighborhood would be all the more thoroughly ransacked. Caterpillars devouring their egg-shells, and so not leaving this "scent" behind them, would oftenest escape, and by degrees this habit would be perpetuated and fixed; and so it is here ; almost invariably the caterpillar hastens to destroy its former prison walls, which it devours to the very base, too closely glued to the leaf to be eaten; probably it breathes more freely when that is done.

But where does it now find itself? Its food at its very feet,--yes; but in the most exposed position possible. Atop the extreme tip of one of the outmost leaves of a spray that projects most freely into the sun and air, just where it can most easily be seen by the passer by; this seems to be the case nine times out of ten. It is, however, probably the safest place from the prowling spiders; but surely not from its flying enemies. What does it do? retreat down the leaf? That would be only to exchange one danger for another, and on its way to a presumed place of safety it would be more sure of detection, because a moving object in nature is alway most easily noticed. No, it eats the nearest bit of leaf down to but not including the midrib, first on one side and then on the other, and then retires to near the tip of the midrib to digest it; subsequent meals it takes in the same way, moving with excessive deliberation along its narrow path and retiring always to the same spot. On this perch it cannot be seen from below, and from the sides and above seems almost or wholly a part of the denuded midrib to which it clings; more particularly when the leaves are in motion by the wind, as they usually are on the trees on which it feeds, particularly in the case of the aspen.

That this mode of life is on the whole an advantage to it is rendered probable from the fact that there are two cases known, in which it is followed very closely by caterpillars of a moth (Notodonta), feeding on the very same plant as species of butterflies with this habit (one in Europe and one in America); while the caterpillars of Basilarchia employ a further device, the actual import of which has been a puzzle. Very soon after birth, when it has eaten but a very few swaths down the leaf, the little fellow constructs a small and loose packet from minute bits of leaf and other rejectamenta, loosely fastened to one another and to the midrib, close to but scarcely touching the eaten edge of the leaf, and as fast as the leaf is eaten, it removes this packet (continually added to until it becomes about as big as a 
small pea), farther and farther clown the midrib away from its perch, always keeping it near the eaten edge. It should be noted that it is so loosely attached, the bits of leaf at all possible angles, that it is moved by the least breath. Meanwhile the caterpillar has been growing larger and more conspicuous and thus in greater peril from its enemies. There are two possible services that this odd packet may render. A spider wandering over the leaf and observing its motion may seize it and thinking it has a prize hurry away with it and leave its architect unharmed. This seems to me rather a strained suggestion, for a wandering spider would probably proceed to investigate it on the spot. Another explanation seems more probable. It should be remembered that the leaves preferred by these creatures as food are mostly such as are easily shaken by the wind, and as the caterpillar moves with the leaf and with all the surrounding leaves, in a contin. ual fluttering in the case of the trembling aspen, and to a less degree in the other food-plants, this of itself is a protection to it, as it would more readily escape observation as an object distinct from the leaves, all being in motion together; but on the more stable leaves like the willow and especially the Rosaceae and the oaks, the motion in a feeble wind would not be sufficient to be serviceable, and here at least the packet comes into play. An object in motion among others at rest is a most noticeable thing, a fact well recognized among animals, as a host of them show when they fear being seen. This packet attached by loose silken threads moves, as stated, with a breath of wind and so would distract attention from its architect near by, who has taken pains to place it at the farthest remove from its perch, while still (to avoid undesirable steps) on its daily track. If this be really its object, it is surely one of the oddest devices in nature.

The species of Basilarchia all pass the winter while in the caterpillar state and but partly grown. The caterpillar has moulted at least once (devouring its cast-off clothing, by the way, doubtless that it may not attract attention) and has to prepare against the inclement season. This it does in a very shrewd way, which is all the more remarkable because no trace or semblance of it is seen in caterpillars of the broods that attain their entire growth in the same season. When the proper time approaches, warned thereto possibly by the dryness of its food, or by the cooler nights, the caterpillar constructs a little nest, sometimes from the still unfinished leaf on which it was born, sometimes from one which it prepares specially at greater pains; this is clone by eating away or biting off the unnecessary parts, and leaving on either side of the base of the leaf little flaps just large enough, when drawn together, bottom side up and meeting above, to form a cylinder into which it can squeeze; a projecting shelf is also left beyond the opening, on which it may stand when ready to crawl in, and upon which it may back out in the spring; the whole 
of the inside and the upper surface of the shelf are then plastered over with a dense coating of brown silk and the flaps drawn together; more than that, with strangest foresight. the petiole of the leaf is thoroughly fastened to the stem by numberless threads passed carefully and tightly around both; into this cylinder it then crawls head foremost, completely filling the cavity, closing the bevelled hinder opening with the sloping tuberculate and sharpened terminal segments, sure to find itself there when the long night of winter is passed. No, not quite sure, for wasps or some other strong predaceous insects will tear this fine castle open and destroy its single occupant. Whether it is an additional safeguard or not, it is an instructive fact that, at least where the winters are most severe, nearly all these hiber nacula are made out of leaves so near the ground that the snow covers them with its warming mantle; and what is more, in certain cases they so closely resemble the winter buds and bursting leaves of the new year that they must sometimes deceive their prowling foes of the early spring.

Shortly after it appears again in the spring and has fed on the tender buds and just opening leaves, it moults again, usually upon the shelf of its hibernaculum but no longer devours its skin, as it quits the immediate neighborhood. It now changes its livery as well and is a most extraordinary looking object, withal very conspicuous. Dark and light green and cream color strive for the mastery and leave it streaked and blotched so that it bears no inconsiderable resemblance, in color at least, to the droppings of some birds, a circumstance which doubtless serves it as some sort of protection. Its body is humped and the bosses bear tubercles which give it a somewhat repulsive aspect; especially a pair a little behind the head are raised aloft thickly studded with prominences, the effect of which is heightened by the creature's habit of arching this part of the body, bending its head to the ground and raising aloft its hinder part, also studded with roughened processes. Altogether it is a rather hideous beast. Then too, if disturbed, it raises the front half of its body from the ground and uses it as a kind of whip-lash throwing it to one side and the other with great violence. When it walks it moves with a slow and cautious tread, its head trembling as if it had the palsy. All this is doubtless to inspire fear to such enemies as might be tempted to attack it, but to how much avail we can hardly tell. It is certainly attacked in considerable numbers by a parasitic hymenopteron, the young of which live within on the juices of the body and escape from the chrysalis when that is formed.

The chrysalis, helpless thing, probably hangs quite exposed upon the stem of the plant which has given the caterpillar nourishment. We know it almost entirely from those raised in confinement. It has an oddly shaped form with a great projection on the back like a Roman nose, and is of a dark green or greenish brown color varied with 
cream color, and smooth as if varnished. This makes it appear like a hanging lump of bird dung, and so again must often prevent its being picked off and devoured by some hungry bird.

When one that has at last escaped all the perils of its youth finally reaches its full development, it is even more conspicuous and exposed than before. Al. though now upon the wing and no doubt often able to escape a pursuer by some quick movement, its natural flight is not swift, and its ordinary movements on the wing are a few quick flutters followed by a sailing motion which is most favorable to capture. Its colors differ of course in the different kinds, and they may in this particular be divided into two classes. One affects a deep rich black blue or blackish purple, and is variegated with light blue and white, the latter partly in the form of bands, on some forming a broad bow across both wings, rendering them most conspicuous and striking objects. They are, too, of a pretty large size, and as they fly mostly in the neighborhood of copses or along shaded roadsides or forest roads, they seem to render themselves by the contrasting back-ground as conspicuous as possible. Another class is of an orange brown color of greater or less depth, while the veins are black, and a black stripe, sometimes accompanied by white dots, crosses the wings. These fly in more open places, more fully exposed to the sun and are scarcely less conspicuous than their fellows. All these butterflies live a considerable time, and indeed the eggs do not mature in the bodies of the females until they have been a fortnight on the wing; and then they do not lay all their eggs at once, or even within a few days, but prolong the operation over many days or even several weeks. To deposit all her eggs therefore, which is the province of course of the female, she must fly amid all the dangers her conspicuous colors offer for about a month, a considerably longer time than the average of butterflies. Previous to egg-laying at least, much of her time is spent upon the ground in company with her fellows, often in great flocks, engrossed in sucking up moisture from the damp earth, from decaying fruits or the droppings of beasts; and so must become a conspicuous and easy prey to her enemies.

What then is to become of this saving remnant of the tribe? How escape from the dangers which it seems to invite? For the individual there would seem to be nothing but chance; but the number of eggs laid under the most favorable circumstances or chances is very considerable; and if only a pair of these finally reaches maturity and is able to fulfil its functions, the number of individuals of the species is maintained. It would seem, however, as if even this chance were small and as if still further protection were needed. And one further protection is afforded, at least to the orange species, in a peculiarity of their life history. Apparently the species of Basilarchia are, at least in New England, normally single brooded; but in not infrequent cases, doubtless 
more frequent in southern than in northern parts, a second or supplementary brood is formed in one season; as the butterfly lays eggs for some time, and all the females are not born at once, the earliest progeny of the earliest females may not infrequently be able to mature in the same season in time for the production of a second brood. This would seem to be a provision on the part of nature to give the species a better chance. That they need it is perhaps evidenced by the fact that the black-veined orange species, which are almost universally more numerous in individuals than the others, have, in regions where one brood is the normal condition of their fellows, always two broods.

But this is not the only advantage the black-veined orange species have, so that we cannot fairly ascribe their greater numbers to this alone. Their very colors are an advantage to them, for in them they mimic species of $E u$ ploeinae, which possess a taste and perhaps an odor offensive to birds and other insectivorous animals; the mimicry is very striking indeed, and is the more remarkable from the fact that the northern species resembles the only species of Euploeinae found in the region it inhabits, while the southern species as well as the southernmost examples of the northern species, resemble another which is more common in the region they inhabit.

It is indeed possible that one of the normally colored species of Basilarchia, one that has least conspicuously contrasted colors, though resplendent with blue and green, is specially protected by the various other devices we have recounted; for certainly it is itself mimicked by one sex of a butterfly of another very distinct group, viz: Semnopsyche diana.

\section{DESCRIPTION OF THE LARVA OF SPHINX LUSCITIOSA.}

BY CAROLINE G. SOUIE, BROOKLINE, MASS.

This larva was found on a poplar shoot, at Sugar Hill, N. H., 2 r July I 887 .

It was then $18.5 \mathrm{~mm}$. long, slender, and green. The head was triangular, pale green, with a pale yellow stripe on each side. The body was brighter green, covered with white granulations, these being less numerous ventrally.

There were seven oblique lines of pale yellow, edged above with green darker than the body, and the last one extended to the tip of the caudal horn. A clear yellow horizontal line on the first three segments, was continued very faintly to the last segment.

The anal shield was of a bluer green than the body, and edged with white.

The feet and props were green; the caudal horn was pinkish above, green beneath, and lined on each side with yellow. Spiracles almost invisible. 

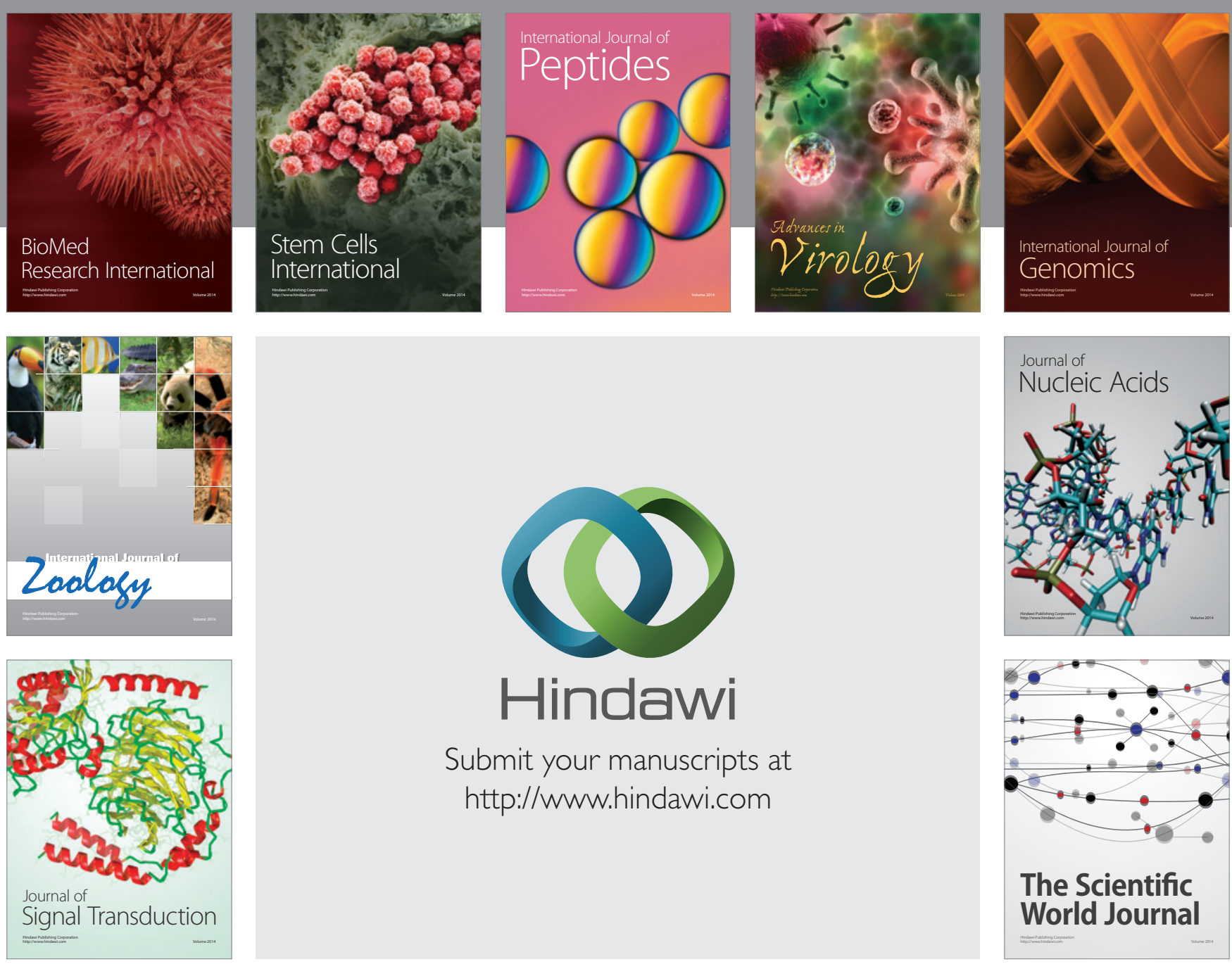

Submit your manuscripts at

http://www.hindawi.com
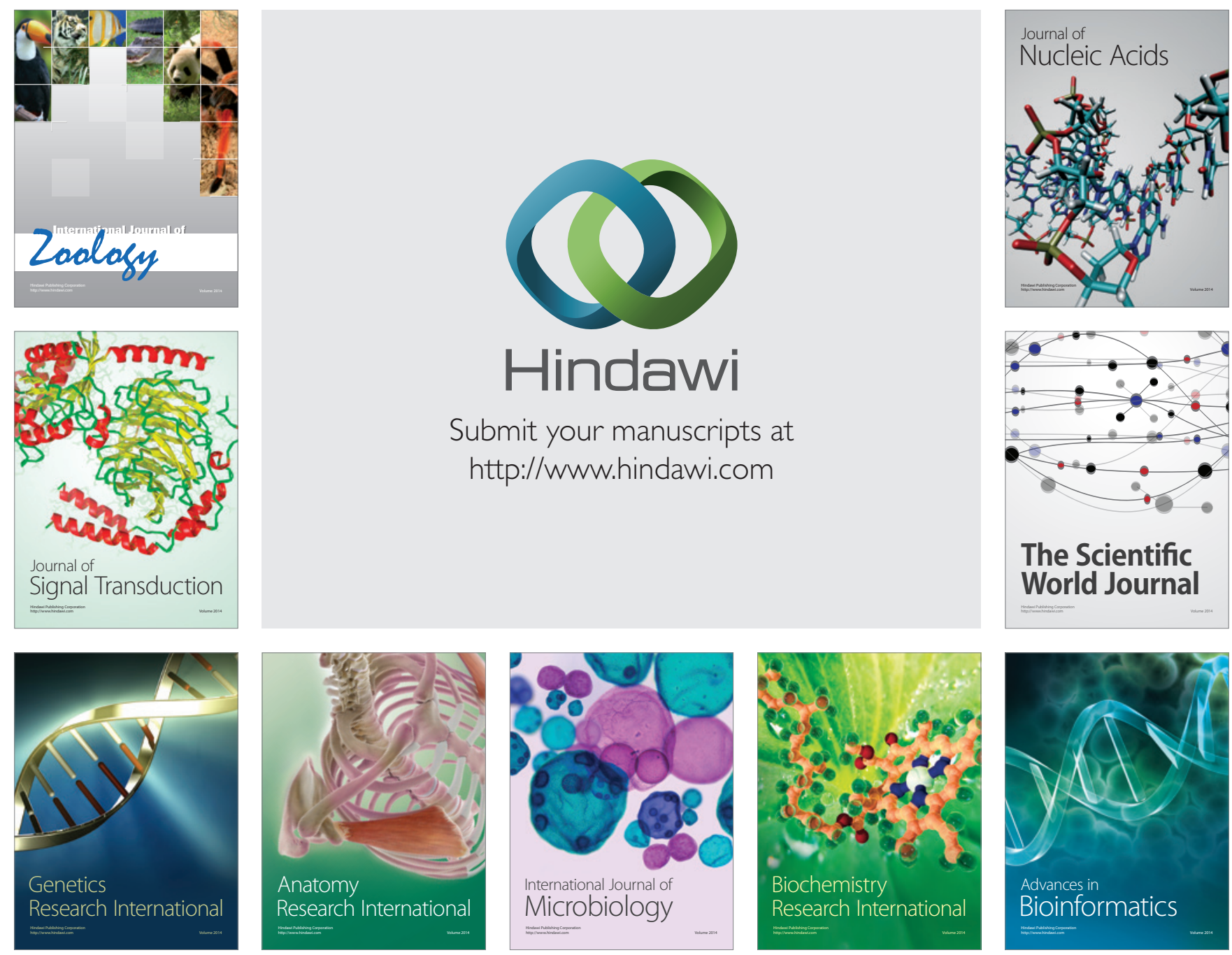

The Scientific World Journal
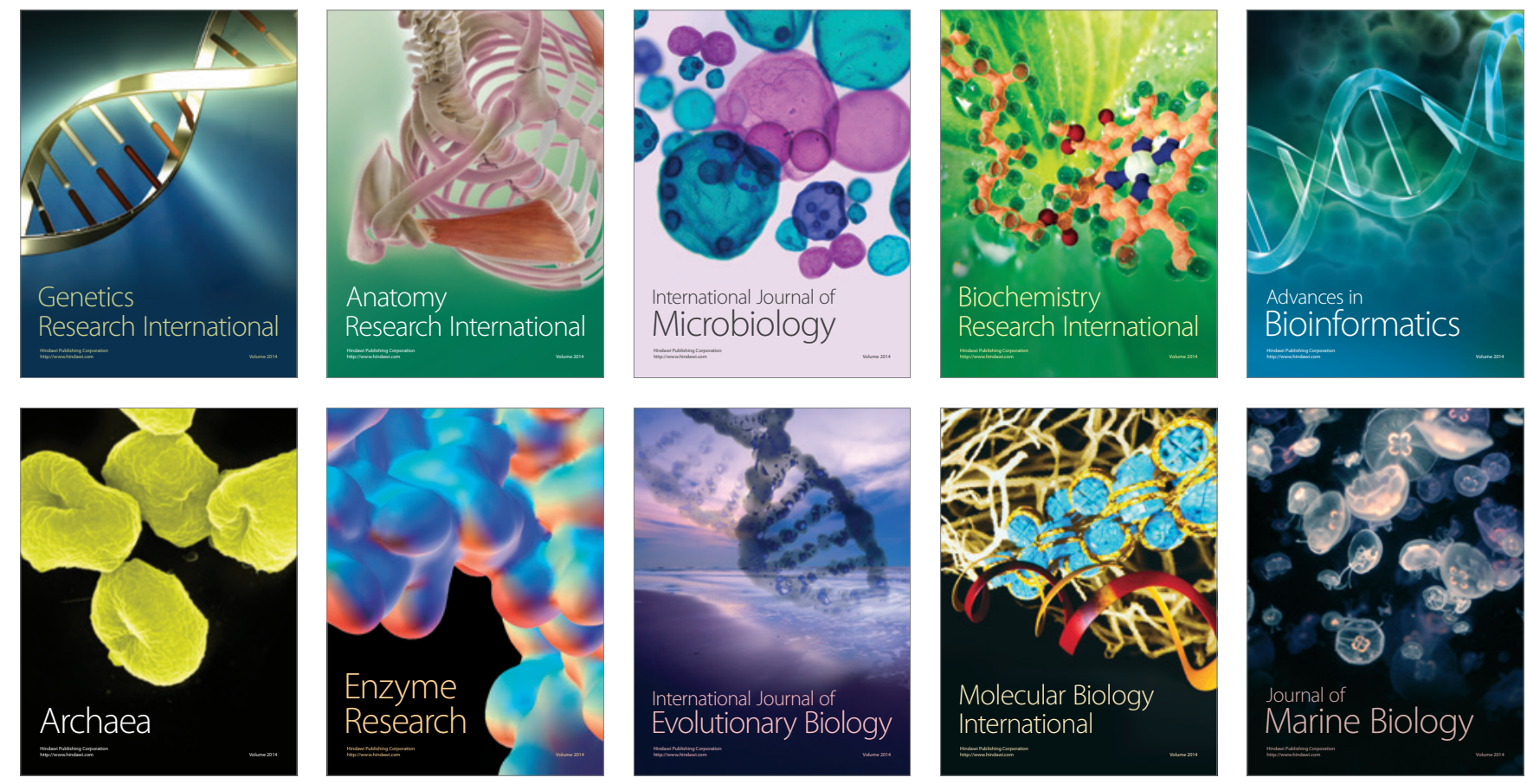